\title{
Journal of Science and Engineering
}

\section{Analisa Kualitas Daya Listrik Pada Gardu Distribusi Universitas Khairun \\ Ramly Rasyid( ${ }^{(a)}$ Mifta Muhammad(b) \\ (1)(2)Jurusan Teknik Elektro}

Universitas Khairun, Ternate, Indonesia
Article history

Received

3 Mei 2021

Accepted

6 mei 2021

*Corresponding author ramlyteknik@gmail.com

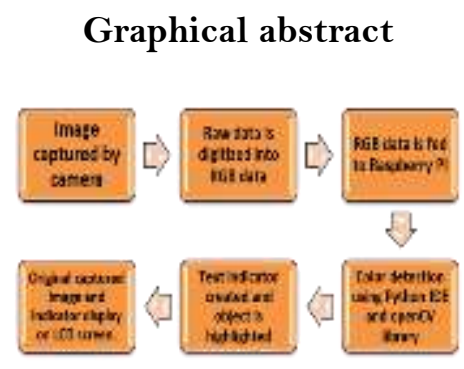

\begin{abstract}
Abstract - The large number of applications of nonlinear loads in the electric power system has made the system current very distorted with a very high percentage of current harmonic content, THD (total harmonic distortion) can damage the power factor compensation capacitor, making the system power factor worse, causing interference. to the telecommunication system, increase system losses, cause various kinds of damage to sensitive electrical equipment, all of which cause the use of electrical energy to be ineffective which results in poor power quality.

In this study, the collection of data obtained was based on methods such as the following, namely the measurement method. This measurement method measures the harmonic voltages and currents caused by non-linear loads.

Keywords: Electric Power Quality, Harmonics
\end{abstract}

\section{Abstrak}

Abstrak - Banyaknya aplikasi beban nonlinier pada sistem tenaga listrik telah membuat arus sistem menjadi sangat terdistorsi dengan persentase kandungan harmonisa arus, THD (total harmonic distortion) yang sangat tinggi ini dapat merusak kapasitor kompensasi faktor daya, membuat faktor daya sistem menjadi lebih buruk, menimbulkan interferensi terhadap sistem telekomunikasi, meningkatkan rugirugi sistem, menimbulkan berbagai macam kerusakan pada peralatan listrik yang sensitif, yang kesemuanya menyebabkan penggunaan energi listrik menjadi tidak efektif yang menyebabkan kualitas daya kurang baik.

Dalam penelitian ini, pengumpulan data-data yang diperoleh berdasarkan metodemetode seperti berikut ini, yaitu Metode pengukuran. Metode [engukuran ini yaitu mengukur tegangan dan arus harmonisa yang disebabkan oleh beban non linier.

Kata Kunci:Kualitas Daya Listrik, Harmonisa

(C) 2021 Penerbit Fakultas Teknik Unkhair. All rights reserved

\subsection{PENDAHULUAN}

Perkembangan tenaga listrik sekarang ini diikuti dengan berkembangnya teknologi elektronik digital dan kontrol, maka hampir semua peralatan listrik sekarang ini berbasiskan sistem mikro elektronik (peralatan elektronik). Piranti elektronik sangat dibutuhkan untuk menunjang aktifitas keseharian baik itu untuk kebutuhan rumah tangga maupun kebutuhan perkantoran, seperti TV, lampu hemat energi, alat pemanas (oven microwave), kulkas, komputer, sistem air conditioner, dan lain sebagainya. Penggunaan peralatan elektronik lebih menguntungkan, karena efisiensinya yang tinggi, pengaturan yang mudah dan mulus, dimensi ruang yang kecil dan lebih fleksibel serta artistik [7].

Penyearah-penyearah jenis ini mempunyai karaktristik non-linier yang mengakibatkan bentuk gelombang arus yang ditariknya dari jala-jala sistem menjadi non-sinusoidal terdistorsi. Menurut Analisis Fourier, bentuk gelombang arus yang 
non-sinusoidal akan terdiri dari arus fundamental dan sejumlah komponen arus harmoni-sa. Oleh karena itu peralatan elektronik merupakan beban non-linier yang menghasilkan harmonisa bagi sistem jala-jala listrik [12][6]

Banyaknya aplikasi beban nonlinier pada sistem tenaga listrik telah membuat arus sistem menjadi sangat terdistorsi dengan persentase kandungan harmonisa arus, THD (total harmonic distortion) yang sangat tinggi. Umumnya arus sistem tenaga listrik yang terdistorsi tersebut didominasi oleh arus harmonisa orde ganjil frekuensi rendah, yakni arus harmonisa orde lima, tujuh, sebelas, dan seterusnya, yang magnitud arus harmonisanya berbanding terbalik dengan orde harmonisanya. Tingginya persentase kandungan harmonisa arus (THD) pada suatu sistem tenaga listrik dapat menyebabkan timbulnya beberapa persoalan harmonisa yang serius pada sistem tersebut dan lingkungannya, seperti terjadinya resonansi pada sistem yang merusak kapasitor kompensasi faktor daya, membuat faktor daya sistem menjadi lebih buruk, menimbulkan interferensi terhadap sistem telekomunikasi, meningkatkan rugi-rugi sistem, menimbulkan berbagai macam kerusakan pada peralatan listrik yang sensitif, yang kesemuanya menyebabkan penggunaan energi listrik menjadi tidak efektif yang menyebabkan kualitas daya kurang baik.

Dari uraian latarbelakang maka maka penulis mengangkat judul penelitian Analisa Kualitas Daya Listrik Pada Gardu Distribusi Universitas Khairun.

\subsection{TINJAUAN PUSTAKA}

\subsection{Kualitas Daya Listrik}

Perhatian terhadap kualitas daya listrik dewasa ini semakin meningkat seiring dengan peningkatan penggunaan energi listrik dan utilitas kelistrikan. Istilah kualitas daya listrik telah menjadi isu penting pada industri tenaga listrik sejak akhir 1980-an. Istilah kualitas daya listrik merupakan suatu konsep yang memberikan gambaran tentang baik atau buruknya mutu daya listrik akibat adanya beberapa jenis gangguan yang terjadi pada sistem kelistrikan [3].

Terdapat empat alasan utama, mengapa para ahli dan praktisi di bidang tenaga listrik memberikan perhatian lebih pada isu kualitas daya listrik [3], yaitu :

1. Pertumbuhan beban-beban listrik dewasa ini bersifat lebih peka terhadap kualitas daya listrik seperti sistem kendali dengan berbasis pada mikroprosesor dan perangkat elektronika daya.

2. Meningkatnya perhatian yang ditekankan pada efisiensi sistem daya listrik secara menyeluruh, sehingga menyebabkan terjadinya peningkatan penggunaan peralatan yang mempunyai efisiensi tinggi, seperti pengaturan kecepatan motor listrik dan penggunaan kapasitor untuk perbaikan faktor daya. Penggunaan peralatan - peralatan tersebut dapat mengakibatkan peningkatkan terhadap tingkat harmonik pada sistem daya listrik, di mana para ahli merasa khawatir terhadap dampak harmonisa tersebut di masa mendatang yang dapat menurunkan kemampuan dari sistem daya listrik itu sendiri.

3. Meningkatnya kesadaran bagi para pengguna energi listrik terhadap masalah kualitas daya listrik. Para pengguna utilitas kelistrikan menjadi lebih pandai dan bijaksana mengenai persoalan seperti interupsi, sags, dan peralihan transien dan merasa berkepentingan untuk meningkatkan kualitas distribusi daya listriknya.

4. Sistem tenaga listrik yang saling berhubungan dalam suatu jaringan interkoneksi, di mana sistem tersebut memberikan suatu konsekuensi bahwa kegagalan dari setiap komponen dapat mengakibatkan kegagalan pada komponen lainnya.

Terdapat beberapa definisi yang berbeda terhadap pengertian tentang kualitas daya listrik, tergantung kerangka acuan yang digunakan dalam mengartikan istilah tersebut. Sebagai contoh suatu pengguna utilitas kelistrikan dapat mengartikan kualitas daya listrik sebagai keandalan, di mana dengan menggunakan angka statistik 99,98\%, sistem tenaga listriknya mempunyai kualitas yang dapat diandalkan. Suatu industri manufaktur dapat mengartikan kualitas daya listrik adalah karakteristik dari suatu catu daya listrik yang memungkinkan peralatan-peralatan yang dimiliki industri tersebut dapat bekerja dengan baik. Karakteristik yang dimaksud tersebut dapat menjadi sangat berbeda untuk berbagai kriteria.

Daya listrik adalah setiap masalah daya listrik yang berbentuk penyimpangan tegangan, arus atau frekuensi yang mengakibatkan kegagalan ataupun kesalahan operasi pada peralatan-peralatan yang terjadi pada konsumen energi listrik. Daya adalah suatu nilai dari energi listrik yang dikirimkan dan didistribusikan, di mana besarnya daya listrik tersebut sebanding dengan perkalian besarnya tegangan dan arus listriknya. Sistem suplai daya listrik dapat dikendalikan oleh kualitas dari tegangan, dan tidak dapat dikendalikan oleh arus listrik karena arus listrik berada pada sisi beban yang bersifat individual, sehingga pada dasarnya kualitas daya adalah kualitas dari tegangan itu sendiri [3].

Parameter-parameter yang dipakai untuk menilai mutu listrik adalah variasi tegangan, variasi frekuensi, ketidakseimbangan, dan harmonik. Dalam sistem penyediaan tenaga listrik secara umum tegangan di titik suplai diijinkan bervariasi $+5 \%$ dan $-10 \%$ (standar PLN) sedangkan untuk variasi frekuensi di sini tidak diatur dalam bentuk standar tetapi lebih banyak diatur dalam bentuk petunjuk operasi. Untuk sistem tenaga listrik Jawa-Bali-Madura diusahakan variasi frekuensi $0,5 \mathrm{~Hz}$, sedangkan daerah lainnya diusahakan tidak melebihi $(1,5 \mathrm{~Hz})$. Harmonik tegangan atau arus diukur dari besarnya masing-masing komponen harmonik terhadap komponen dasarnya dinyatakan dalam prosennya. Untuk memperoleh suatu parameter yang dipakai untuk menilai harmonik tersebut dipakai cacat harmonik total (Total Harmonic Distortion).

\subsection{Harmonisa}


Kecenderungan penggunaan beban-beban elektronik dalam jumlah besar dalam selang waktu kira-kira duapuluh tahun terakhir pada saat ini telah menimbulkan masalah yang tidak terkirakan sebelumnya. Berbeda dengan beban-beban listrik yang menarik arus sinusoidal (sebentuk dengan tegangan yang menyuplainya), beban-beban elektronik menarik arus dengan bentuk nonsinusoidal, walaupun disuplai dari sumber tegangan sinusoidal. Beban yang memiliki sifat ini disebut sebagai beban nonlinier.

Arus yang tidak berbentuk sinusoidal tersebut mengintrodusir komponen arus frekuensi tinggi yang terinjeksi ke jala-jala, yang dikenal dengan nama arus harmonisa (karena itu fenomena ini seringkali disebut dengan polusi harmonisa). Arus harmonisa ini ternyata menimbulkan sangat banyak implikasi negatif, baik bagi pelanggan maupun power provider. Kerugian akibat harmonisa mencakup aspek teknis, biaya dan keandalan. [2]

\subsection{BebanLinier dan Non Linier}

Beban dalam pelayanan tenaga listrik terdiri dari bebab linier dan beban non linier, beban non linier inilah yang sangat mempengaruhi kualitas daya listrik.

\subsubsection{BebanLinier}

Beban linier adalah beban yang komponen arusnya proporsional terhadap tegangannya. Terdapat hubungan yang linier antara arus dan tegangan sehingga bentuk gelombang arus akan sama dengan bentuk gelombang tegangannya, seperti terlihat pada Gambar 2.1 di bawah ini. Beban linier menyerap arus sinusoidal bila disuplai oleh tegangan sinusoidal. Contoh beban linier antara lain pemanas, lampu pijar, dan lainnya[6].

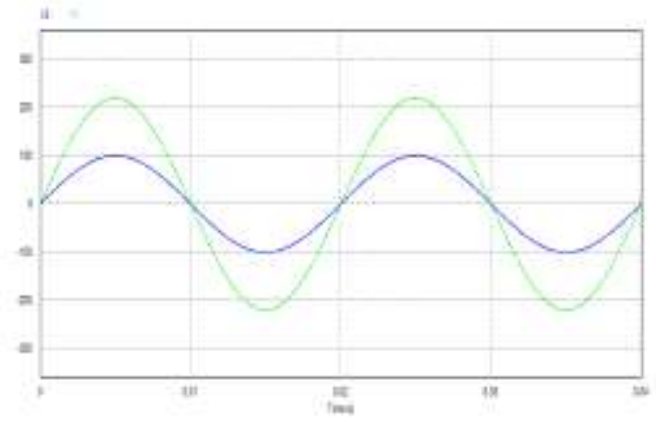

Gambar 2.1 Bentuk Gelombang Tegangan Beban Linier

\subsubsection{Beban Non Linier}

Beban yang komponen arusnya tidak proporsional terhadap komponen tegangannya, sehingga bentuk gelombang arusnya tidak sama dengan bentuk gelombang tegangannya. Tidak terdapat hubungan yang linier antara arus dan tegangan. Beban nonlinier menyerap arus non sinusoidal demikian juga arus harmonik, walaupun disuplai oleh tegangan sinusoidal. Seperti gambar 2.2 .

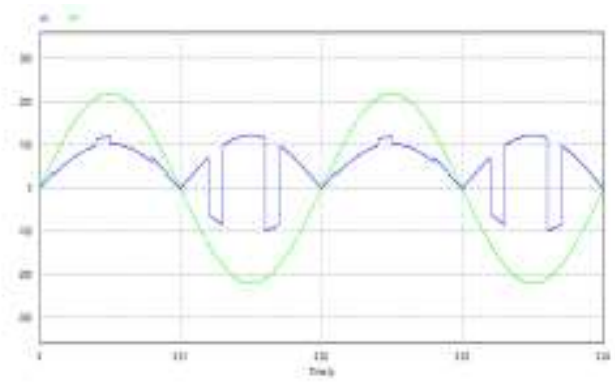

Gambar 2.2 Bentuk Gelombang Tegangan Beban Non Linier

Contoh beban nonlinier antara lain penyearah (power supply, UPS, komputer, pengaturan kecepatan motor, lampu-lampu pelepasan), alat-alat ferromagnetik, motor DC, dan tungku busur api, serta lainnya [6]

\subsection{Distorsi Harmonik Total (Total Harmonic Distortion / THD)}

THD adalah ukuran dari nilai efektif bentuk gelombang yang terdistorsi dari komponen harmonisa. THD disebut juga faktor distorsi (distortion factor). THD berlaku untuk arus dan tegangan. THD digambarkan sebagai nilai rms dari harmonik di atas fundamental, dibagi dengan nilai rms fundamental. DC diabaikan. [5]. Jadi untuk arus [4],

$$
T H D_{i}=\frac{\sqrt{\sum_{k=2}^{\infty}\left(\frac{I_{k}}{\sqrt{2}}\right)^{2}}}{\frac{l_{1}}{\sqrt{2}}}=\frac{\sqrt{\frac{1}{2} \sum_{k=2}^{\infty} I_{k}^{2}}}{\frac{l_{1}}{\sqrt{2}}} \ldots \ldots \ldots
$$




\subsection{Distorsi Faktor Daya}

$$
T H D_{V}=\frac{\sqrt{\sum_{k=1}^{\infty}\left(\frac{V_{k}}{\sqrt{2}}\right)^{2}}}{\frac{V_{1}}{\sqrt{2}}}=\frac{\sqrt{\frac{1}{2} \sum_{k=2}^{\infty} v_{k}^{2}}}{\frac{V_{1}}{\sqrt{2}}} \ldots \ldots \ldots
$$

Dimana : $\mathrm{V}_{1}=$ Tegangan fundamental (Volt)

$\mathrm{V}_{\mathrm{k}}=$ Tegangan harmonisa (Volt)

$\mathrm{I}_{1}=$ Arus fundamental (Ampere)

$\mathrm{I}_{\mathrm{k}}=$ Arus harmonisa (Ampere)

Tegangan dan arus yang mengandung komponen harmonic mempunyai nilai RMS sebagai berikut:

$$
\begin{aligned}
& V_{r m s}=V_{1} \\
& \sqrt{1+\left(\frac{T H D_{V}}{100}\right)^{2}} \ldots \ldots \ldots \ldots \ldots \ldots \ldots \ldots \ldots \ldots \\
& I_{r m s}=I_{r m s} I_{1}=I_{1} \\
& \sqrt{1+\left(\frac{T H D_{l}}{100}\right)^{2}} \\
& P f_{\text {tot }}=\frac{P}{V I \sqrt{1+\left(\frac{T H D_{V}}{100}\right)^{2}} \sqrt{1+\left(\frac{T H D_{l}}{100}\right)^{2}}} . . \text { (2.5) }
\end{aligned}
$$

Sebagian besar kasus hanya sedikit porsidaya rata-rata yang disumbangkan oleh komponen-komponen harmonic dan total distorsi tegangan kurang dari 10\% sehingga:

$$
\begin{gathered}
P f_{\text {tot }}=\frac{P_{1}}{V_{1} I_{1}} \frac{1}{\sqrt{1+\left(\frac{T H D_{1}}{100}\right)^{2}}} \ldots \ldots \ldots \ldots \ldots(2.6) \\
P f_{\text {tot }}=\cos \left(\Theta_{1}-s_{1}\right) \cdot P f_{\text {dist } \ldots(2.7)}
\end{gathered}
$$

Dimana $\cos \left(\Theta_{1}-s_{1}\right)$ dikenal sebagai displacement factor daya dan $P f_{\text {dist }}$ disebut distortion faktor daya [1].

\subsection{Dampak Harmonik}

Setiap komponen sistem tenaga dapat dipengaruhi oleh harmonic walaupun dengan akibat yang berbeda. Namun demikian, komponen tersebut akan mengalami penurunan kerja dan bahkan akan mengalami kerusakan. Salah satu dampak yang umum dialami adalah panas lebih pada kawat netral dan transformator sebagai akibat timbulnya harmonik ketiga yang dibangkitkan oleh peralatan listrik satu fase. Arus beban setiap fase dari beban linier yang seimbang pada frekuensi dasarnya akan saling mengurangi sehingga arus netral menjadi nol. Sebaliknya beban tak linier satu fase akan menimbulkan harmonic kelipatan tiga ganjil yang disebut triplen.harmonic (harmonik ke-3. ke-9, ke-15, dst. Harmonik ini tidak menghilangkan arus netral, tetapi dapat menghasilkan arus netral yang melebihi arus fasenya [7].

Selain itu ada beberapa akibat yang ditimbulkan oleh adanya harmonikdalam sistem tenaga listrik, antara lain:

1. Timbulnya getaran mekanis pada panel listrik yang merupakan getaran resonansi mekanis akibat arus harmonik frekuensi tinggi.

2. Harmonik dapat menimbulkan tambahan torsi pada KWH meter jenis elektromekanis yang menggunakan program induksi berputar. Sebagai akibatnya, putaran piring akan lebih cepat atau terjadi kesalahan ukur dalam KWH meter karena piringan induksi tersebut dirancang hanya pada frekuensi dasar.

3. Pemutusan beban dapat bekerja dibawah arus pengenalnya atau mungkin tidak bekerja pada arus pengenalnya. Pemutus beban yang dapat terhindar dari gangguan harmonik umumnya adalah pemutus beban yang mempunyai respon terhadap arus rms sebenarnya (true rms current) atau kenaikan temperatur karena arus lebih.

\subsection{METODE PENELITIAN}

\subsection{Data Penelitian}

Data-data yang dipergunakan dalam penelitian ini antara lain :

1. Data single line diagram sistem kelistrikan di gardu distribusi Universitas Khairun

2. Data pengukuran tegangan dan arus pada gardu distribusi Universitas Khairun

3. Data pengukuran factor daya pada gardu distribusi Universitas Khairun

\subsection{Teknik pengumpulan data}

Dalam penelitian ini, pengumpulan data-data yang diperoleh berdasarkan metode-metode seperti berikut ini, yaitu Metode pengukuran. Metode Pengukuran ini yaitu mengukur tegangan, arus harmonisa, dan distorsi factor daya yang disebabkan oleh beban non linier. 


\subsection{Teknik Analisis Data}

Teknik analisis data dalam penelitian ini dilakukan dengan tahapan sebagai berikut:

1. Mengukur tegangan dan arus pada panel induk di gedung rektorat Universitas Khairun.

2. Mengukur total kapasitas daya aktif, reaktif, dan daya semu

3. Mengukur dan menganalisis Total Harmonic Distortion, baik THD maupun THD

4. Membandingkan batas maksimum THD dan distorsi faktor daya berdasarkan IEEE standard 519-1992.

5. Mengukur dan menganalisa distorsi factor daya

\subsection{Diagram Alur Analisis}

Diagram alur penelitian ini dapat dilihat pada gambar 3.1.

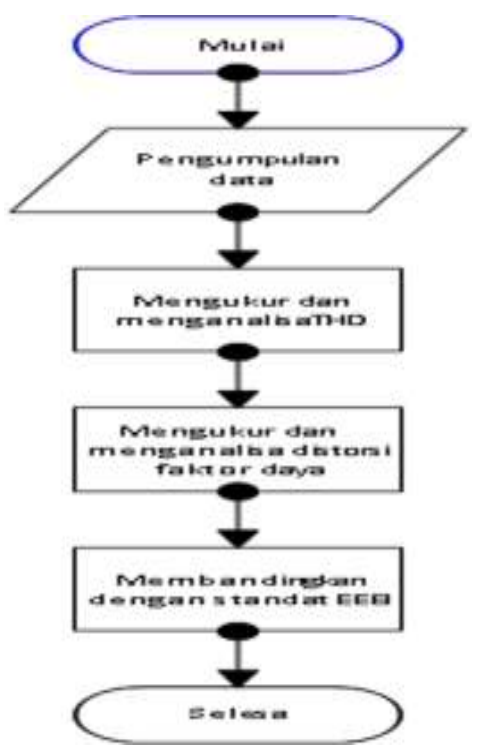

Gambar 3.1. Diagram Alir Penelitian

\subsection{HASIL PENELITIAN}

\subsection{Hasil Pengukuran}

Hasil pengukuran terhadap besaran listrik trafo distribusi pada Gardu Universitas Khairun dilakukan pada sisi sekunder transformator distribusi di panel induk gedung rektorat Universitas Khairun menggunakan alat ukur power quality Analiser merek Metrel 2852 yang dilakukan pada tanggal 21 Agustus 2020 dapat dilihat sebagai berikut:

a. Hasil Pengukuran Jam 10.00

Hasil pengukuran jam 10.00 dapat dilihat pada tabel 4.1 sedang diagram fasornya dapat dilihat pada gambar 4.1

Tabel 1 Hasil Pengukuran pada Jam 10.00

\begin{tabular}{|c|c|c|c|c|c|c|}
\hline Symbol & Name & L1 & L2 & L3 & LN & Unit \\
\hline $\mathrm{U}$ & Voltage & 221.66 & 218.84 & 221.86 & 1.1386 & $\mathrm{~V}$ \\
\hline 1 & Current & 49.144 & 72.896 & 54.771 & 3.2967 & A \\
\hline$f$ & Frequency & 50.041 & \begin{tabular}{|l|l}
--- & \\
\end{tabular} & \begin{tabular}{|l|}
--- \\
\end{tabular} & \begin{tabular}{|l|}
--- \\
\end{tabular} & $\mathrm{Hz}$ \\
\hline THD U & Voltage THD & 1.2189 & 1.1721 & 1.4399 & 21.285 & $\%$ \\
\hline THD U & Voltage THD & 2.6973 & 2.5606 & 3.1898 & 0.2131 & $\mathrm{~V}$ \\
\hline THD I & Current THD & 4.2253 & 10.031 & 5.087 & 3.2386 & $\%$ \\
\hline THD I & Current THD & 2.0723 & 7.2679 & 2.7798 & 0.106 & A \\
\hline $\mathrm{P}$ & Active Power & 9.1717 & 14.349 & 11.711 & --- & kW \\
\hline $\mathrm{N}$ & Reactive Power & 5.8767 & 6.97 & 3.2432 & --- & kvar \\
\hline $\mathrm{S} / \mathrm{Se}$ & Phase Apparent Power & 10.893 & 15.952 & 12.151 & --- & kVA \\
\hline $\mathrm{PF}$ & Phase Power Factor & 0.842 & 0.8995 & 0.9637 & --- & \\
\hline DPF / DPF & Phase Displacement Factor & 0.8429 & 0.9044 & 0.965 & --- & \\
\hline
\end{tabular}




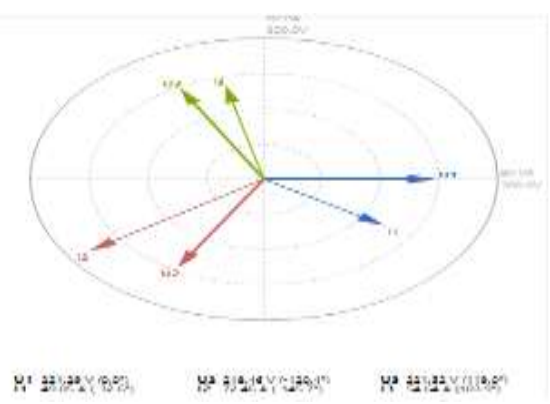

Gambar 4.1 Diagram Fasor jam 10.00

b. Hasil Pengukuran pada Jam 10.15

Hasil pengukuran jam 10.15 dapat dilihat pada tabel 4.2 sedang diagram fasornya dapat dilihat pada gambar 4.2

Tabel 2 Hasil Pengukuran pada Jam 10.15

\begin{tabular}{|c|c|c|c|c|c|c|}
\hline Symbol & Name & L1 & L2 & L3 & LN & Unit \\
\hline $\mathrm{U}$ & Voltage & 221.65 & 219.07 & 221.01 & 1.077 & $\mathrm{~V}$ \\
\hline 1 & Current & 50.136 & 71.956 & 63.472 & 3.1737 & A \\
\hline$f$ & Frequency & 50.044 & --- & --- & --- & $\mathrm{Hz}$ \\
\hline THD U & Voltage THD & 1.2429 & 1.1485 & 1.3361 & 21.541 & $\%$ \\
\hline THD U & Voltage THD & 2.7502 & 2.5123 & 2.9482 & 0.2011 & $\mathrm{~V}$ \\
\hline THD I & Current THD & 4.4216 & 8.8528 & 4.3918 & 3.8277 & $\%$ \\
\hline THD I & Current THD & 2.2122 & 6.3388 & 2.7822 & 0.1212 & A \\
\hline $\mathrm{P}$ & Active Power & 9.4982 & 14.181 & 13.685 & --- & $\mathrm{kW}$ \\
\hline $\mathrm{N}$ & Reactive Power & 5.7688 & 6.8847 & 3.0813 & --- & kvar \\
\hline $\mathrm{S} / \mathrm{Se}$ & Phase Apparent Power & 11.113 & 15.764 & 14.028 & --- & kVA \\
\hline PF & Phase Power Factor & 0.8547 & 0.8996 & 0.9756 & --- & \\
\hline DPF / DPF+ & Phase Displacement Factor & 0.8556 & 0.9035 & 0.9765 & --- & \\
\hline
\end{tabular}

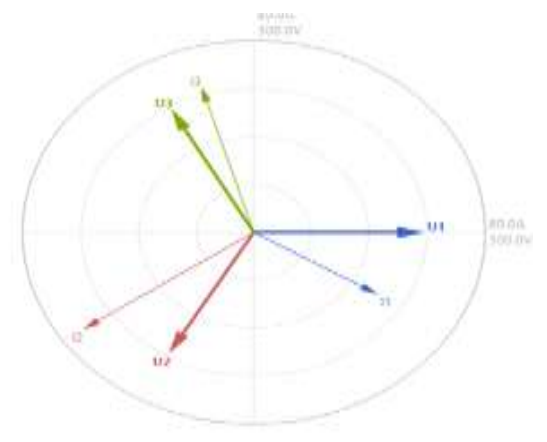

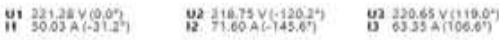

Gambar 4.2 Diagram Fasor jam 10.15

c. Hasil Pengukuran pada Jam 10.30

Hasil pengukuran jam 10.30 dapat dilihat pada tabel 4.3 sedang diagram fasornya dapat dilihat pada gambar 4.3

Tabel 3 Hasil Pengukuran pada Jam 10.30

\begin{tabular}{|l|l|r|r|r|r|l|}
\hline Symbol & Name & L1 & L2 & L3 & LN & Unit \\
\hline U & Voltage & 220.36 & 218.98 & 220.92 & 0.826 & V \\
\hline I & Current & 61.542 & 72.662 & 64.734 & 3.0854 & A \\
\hline f & Frequency & 50.033 & --- & --- & -- & Hz \\
\hline THD U & Voltage THD & 1.1965 & 1.1721 & 1.3322 & 30.723 & $\%$ \\
\hline THD U & Voltage THD & 2.6325 & 2.5627 & 2.9383 & 0.1991 & V \\
\hline THD I & Current THD & 3.547 & 9.588 & 3.7887 & 4.0281 & $\%$ \\
\hline THD I & Current THD & 2.1792 & 6.9284 & 2.4479 & 0.1238 & A \\
\hline P & Active Power & 12.238 & 14.299 & 14.004 & --- & kW \\
\hline N & Reactive Power & 5.8414 & 6.9799 & 2.9012 & --- & kvar \\
\hline S / Se & Phase Apparent Power & 13.561 & 15.912 & 14.301 & --- & kVA \\
\hline PF & Phase Power Factor & 0.9025 & 0.8987 & 0.9792 & --- & \\
\hline DPF / DPF+ & Phase Displacement Factor & 0.9032 & 0.9033 & 0.98 & --- & \\
\hline
\end{tabular}




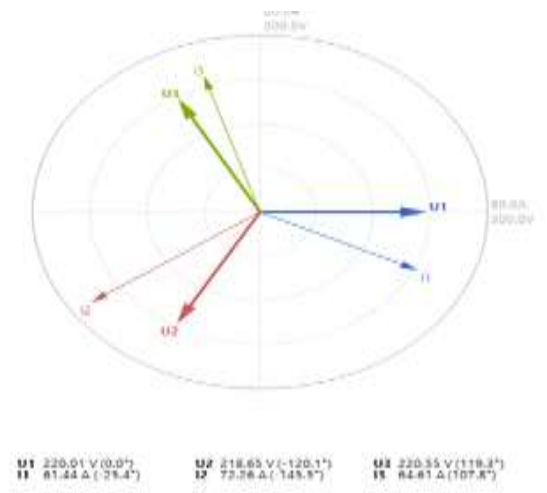

Gambar 4.3 Diagram Fasor jam 10.30

d. Hasil Pengukuran pada Jam 10.45

Hasil pengukuran jam 10.45 dapat dilihat pada tabel.4 sedang diagram fasornya dapat dilihat pada gambar 4.4

Tabel 4 Hasil Pengukuran pada Jam 10.45

\begin{tabular}{|l|l|r|r|r|l|l|}
\hline Symbol & Name & L1 & L2 & L3 & LN & Unit \\
\hline $\mathrm{U}$ & Voltage & 220.62 & 218.92 & 220.96 & 0.8663 & V \\
\hline $\mathrm{I}$ & Current & 59.413 & 72.404 & 63.909 & 3.4052 & $\mathrm{~A}$ \\
\hline $\mathrm{f}$ & Frequency & 50.033 & --- & --- & --- & $\mathrm{Hz}$ \\
\hline THD U & Voltage THD & 1.1869 & 1.1866 & 1.3655 & 33.201 & $\%$ \\
\hline THD U & Voltage THD & 2.6143 & 2.5935 & 3.0123 & 0.2379 & $\mathrm{~V}$ \\
\hline THDI & Current THD & 3.3446 & 9.4927 & 6.0844 & 4.6261 & $\%$ \\
\hline THDI & Current THD & 1.9838 & 6.8353 & 3.876 & 0.1442 & $\mathrm{~A}$ \\
\hline $\mathrm{P}$ & Active Power & 11.659 & 14.237 & 13.815 & --- & $\mathrm{kW}$ \\
\hline $\mathrm{N}$ & Reactive Power & 5.9889 & 6.9681 & 2.9255 & --- & $\mathrm{k}$ \\
\hline $\mathrm{S} / \mathrm{Se}$ & Phase Apparent Power & 13.108 & 15.851 & 14.121 & --- & $\mathrm{k}$ VA \\
\hline PF & Phase Power Factor & 0.8895 & 0.8982 & 0.9783 & --- & \\
\hline DPF / DPF+ & Phase Displacement Factor & 0.8901 & 0.9026 & 0.9806 & --- & \\
\hline
\end{tabular}

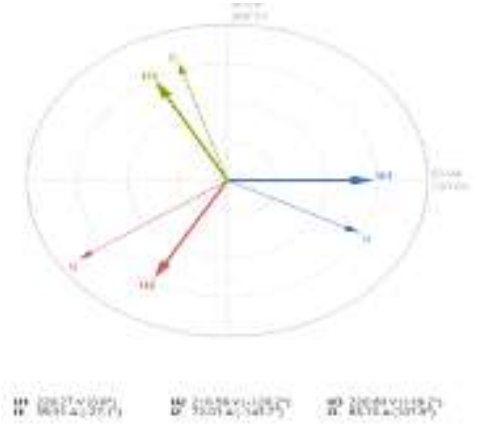

Gambar 4.4 Diagram Fasor jam 10.45

e. Hasil Pengukuran pada Jam 11.00

Hasil pengukuran jam 11.00 dapat dilihat pada tabel 5 sedang diagram fasornya dapat dilihat pada gambar 4.5

Tabel 5 Hasil Pengukuran pada Jam 11.00

\begin{tabular}{|c|c|c|c|c|c|c|c|}
\hline Symbol & Name & L1 & L2 & L3 & LN & Total & Unit \\
\hline U & Voltage & 220.8 & 218.82 & 220.16 & 1.0116 & |--- & $\mathrm{V}$ \\
\hline I & Current & 57.066 & 72.723 & 67.696 & 3.0887 & 7--- & A \\
\hline$f$ & Frequency & 50.045 & --- & --. & --. & -.- & $\mathrm{Hz}$ \\
\hline THD U & Voltage THD & 1.1636 & 1.1835 & 1.3762 & 27.35 & 5 & $\%$ \\
\hline THDU & Voltage THD & 2.5647 & 2.5857 & 3.0253 & 0.2311 & -.- & $\mathrm{V}$ \\
\hline THDI & Current THD & 3.9754 & 9.728 & 4.4633 & 4.7304 & 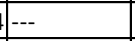 & $\%$ \\
\hline THDI & Current THD & 2.2644 & 7.034 & 3.0154 & 0.1457 & (--- & A \\
\hline $\mathrm{P}$ & Active Power & 11.113 & 14.279 & 14.632 & --- & 40.024 & $\mathrm{~kW}$ \\
\hline$N$ & Reactive Power & 5.9375 & 7.0243 & 2.8355 & -- & 15.797 & kvar \\
\hline $\mathrm{S} / \mathrm{Se}$ & Phase Apparent Power & 12.6 & 15.913 & 14.904 & -- & 43.659 & kVA \\
\hline $\mathrm{PF}$ & Phase Power Factor & 0.882 & 0.8973 & 0.9817 & --- & 0.9167 & \\
\hline DPF / DPF+ & Phase Displacement Factor & 0.8855 & 0.9027 & 0.9839 & --- & 0.934 & \\
\hline
\end{tabular}




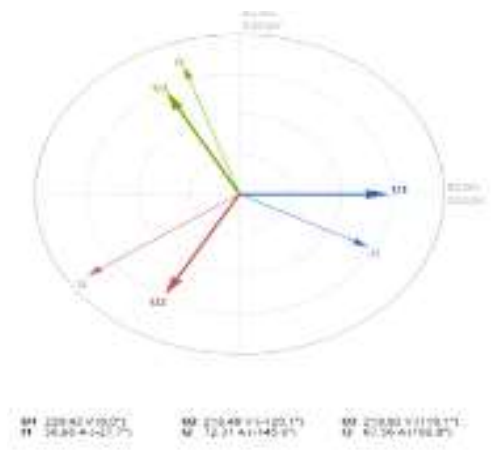

Gambar 4.5 Diagram Fasor jam 11.00

f. Hasil Pengukuran pada Jam 11.15

Hasil pengukuran jam 11.15 dapat dilihat pada tabel 4.6 sedang diagram fasornya dapat dilihat pada gambar 4.6

Tabel 4.6 Hasil Pengukuran pada Jam 11.15

\begin{tabular}{|c|c|c|c|c|c|c|}
\hline Symbol & Name & L1 & L2 & L3 & LN & Unit \\
\hline $\mathrm{U}$ & Voltage & 220.68 & 218.67 & 219.87 & 1.0116 & $\mathrm{~V}$ \\
\hline I & Current & 57.66 & 72.807 & 68.303 & 3.0565 & A \\
\hline$f$ & Frequency & 50.04 & -- & --- & --- & $\mathrm{Hz}$ \\
\hline THDU & Voltage THD & 1.1847 & 1.1966 & 1.4649 & 31.167 & $\%$ \\
\hline THDU & Voltage THD & 2.6104 & 2.6123 & 3.2155 & 0.2547 & $\mathrm{~V}$ \\
\hline THDI & Current THD & 4.2242 & 10.019 & 5.2717 & 5.3608 & $\%$ \\
\hline THDI & Current THD & 2.4312 & 7.2501 & 3.591 & 0.1634 & $A$ \\
\hline $\mathrm{P}$ & Active Power & 11.289 & 14.272 & 14.741 & --- & kW \\
\hline $\mathrm{N}$ & Reactive Power & 5.8711 & 7.0547 & 2.8699 & --- & kvar \\
\hline $\mathrm{S} / \mathrm{Se}$ & Phase Apparent Power & 12.725 & 15.921 & 15.018 & --- & kVA \\
\hline PF & Phase Power Factor & 0.8872 & 0.8965 & 0.9816 & --- & \\
\hline DPF / DPF+ & Phase Displacement Factor & 0.8882 & 0.9014 & 0.9834 & --- & \\
\hline
\end{tabular}

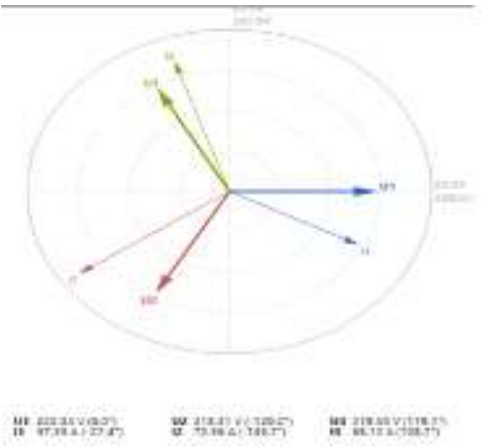

Gambar 4.6 Diagram Fasor jam 11.15

g. Hasil Pengukuran pada Jam 11.30

Hasil pengukuran jam 10.30 dapat dilihat pada tabel 7 sedang diagram fasornya dapat dilihat pada gambar 4.7

Tabel 7 Hasil Pengukuran pada Jam 11.30

\begin{tabular}{|l|l|r|r|r|r|l|}
\hline Symbol & Name & L1 & L2 & L3 & LN & Unit \\
\hline $\mathrm{U}$ & Voltage & 220.71 & 218.01 & 219.7 & 1.197 & $\mathrm{~V}$ \\
\hline $\mathrm{I}$ & Current & 58.177 & 74.804 & 70.148 & 3.1198 & $\mathrm{~A}$ \\
\hline $\mathrm{f}$ & Frequency & 50.033 & --- & --- & --- & $\mathrm{Hz}$ \\
\hline THD U & Voltage THD & 1.2307 & 1.1801 & 1.3962 & 23.351 & $\%$ \\
\hline THD U & Voltage THD & 2.7117 & 2.5689 & 3.0624 & 0.2419 & $\mathrm{~V}$ \\
\hline THD I & Current THD & 3.4809 & 12.888 & 6.5574 & 5.0625 & $\%$ \\
\hline THD I & Current THD & 2.0216 & 9.551 & 4.5845 & 0.1575 & $\mathrm{~A}$ \\
\hline P & Active Power & 11.369 & 14.725 & 15.17 & -- & kW \\
\hline $\mathrm{N}$ & Reactive Power & 5.9669 & 7.0087 & 2.7184 & -- & kvar \\
\hline S / Se & Phase Apparent Power & 12.84 & 16.308 & 15.411 & --- & kVA \\
\hline PF & Phase Power Factor & 0.8855 & 0.9029 & 0.9843 & --- & \\
\hline DPF / DPF+ & Phase Displacement Factor & 0.8861 & 0.911 & 0.9867 & -- & \\
\hline
\end{tabular}




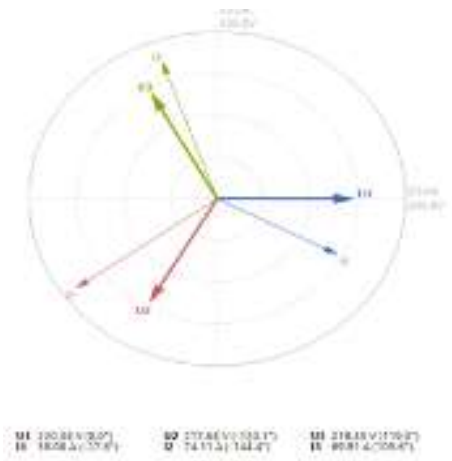

Gambar 4.7 Diagram Fasor jam 11.30

h. Hasil Pengukuran pada Jam 11.45

Hasil pengukuran jam 11.45 dapat dilihat pada tabel 8 sedang diagram fasornya dapat dilihat pada gambar 4.8

Tabel 8 Hasil Pengukuran pada Jam 11.45

\begin{tabular}{|c|c|c|c|c|c|c|}
\hline Symbol & Name & L1 & L2 & L3 & LN & Unit \\
\hline$U$ & Voltage & 220.4 & 218.61 & 219.5 & 0.9048 & V \\
\hline I & Current & 60.213 & 73.438 & 70.226 & 3.048 & A \\
\hline$f$ & Frequency & 50.04 & --- & --- & --- & $\mathrm{Hz}$ \\
\hline THD U & Voltage THD & 1.2527 & 1.1837 & 1.3828 & 35.296 & $\%$ \\
\hline THD U & Voltage THD & 2.7567 & 2.5835 & 3.0301 & 0.258 & $\mathrm{~V}$ \\
\hline THD I & Current THD & 4.23 & 10.871 & 6.6273 & 5.3201 & $\%$ \\
\hline THDI & Current THD & 2.5419 & 7.9268 & 4.6381 & 0.1617 & $A$ \\
\hline$P$ & Active Power & 11.99 & 14.359 & 15.157 & --- & kW \\
\hline $\mathrm{N}$ & Reactive Power & 5.6893 & 7.1809 & 2.8033 & --- & kvar \\
\hline $\mathrm{S} / \mathrm{Se}$ & Phase Apparent Power & 13.271 & 16.055 & 15.414 & --- & kVA \\
\hline $\mathrm{PF}$ & Phase Power Factor & 0.9034 & 0.8944 & 0.9833 & --- & \\
\hline DPF / DPF+ & Phase Displacement Factor & 0.9044 & 0.9002 & 0.9859 & --- & \\
\hline
\end{tabular}

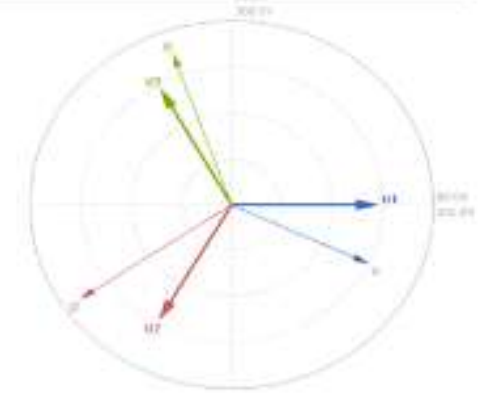

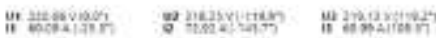

Gambar 4.8 Diagram Fasor jam 11.45

\subsection{Analisis Data}

Data yang dianalisis pada penelitian ini adalah data perfasa dari pengukuran sehingga datanya dipisahkan atau direkapitulasi pada tiap-tiap fasa dan menganalisis harmonisnya.

a. Analisis Pada Fasa R

Analisis pada Fasa R ini menggunakan data rekapitulasi fasa $\mathrm{R}$ yang terlihat pada Tabel 4.9, sedang spectrum harmonisa tegangan dan arus dapat dilihat pada gambar 9 dan gambar 10 
Tabel 4.9 Rekapitulasi Data Fasa R

\begin{tabular}{|c|c|c|c|c|}
\hline \multirow{4}{*}{$\begin{array}{l}\text { Parameter } \\
\text { gan rms (V) } \\
\text { ms (A) }\end{array}$} & \multicolumn{4}{|c|}{ Waktu Pengukuran } \\
\hline & Jam 10.00 & Jam 10.15 & Jam 10.30 & Jam 10.45 \\
\hline & 221.66 & 221.65 & 220.36 & 220.62 \\
\hline & 49.144 & 50.136 & 61.542 & 59.413 \\
\hline Setral (A) & 3.2967 & 3.1737 & 3.0854 & 3.4052 \\
\hline$(\%)$ & 1.2189 & 1.2429 & 1.1965 & 1.1869 \\
\hline (\%) & 4.2253 & 4.4216 & 3.547 & 3.3446 \\
\hline ensi (Hz) & 50.041 & 50.044 & 50.033 & 50.033 \\
\hline ) & 9.1717 & 9.4982 & 12.238 & 11.659 \\
\hline A) & 5.8767 & 5.7688 & 5.8414 & 5.9889 \\
\hline \multirow{3}{*}{$\overline{\text { AR) }}$} & 10.893 & 11.113 & 13.561 & 13.108 \\
\hline & 0.842 & 0.8547 & 0.9025 & 0.8895 \\
\hline & 0.8429 & 0.8556 & 0.9032 & 0.8901 \\
\hline \multirow{2}{*}{ 'arameter } & \multicolumn{4}{|c|}{ Waktu Pengukuran } \\
\hline & Jam 11.00 & Jam 11.15 & Jam 11.30 & Jam 11.45 \\
\hline \multirow{2}{*}{$\begin{array}{l}\operatorname{gan} r m s(V) \\
\text { ms (A) }\end{array}$} & 220.8 & 220.68 & 220.71 & 220.4 \\
\hline & 57.066 & 57.66 & 58.177 & 60.213 \\
\hline Netral (A) & 3.0887 & 3.0565 & 3.1198 & 3.048 \\
\hline$(\%)$ & 1.1636 & 1.1847 & 1.2307 & 1.2527 \\
\hline (\%) & 3.9754 & 4.2242 & 3.4809 & 4.23 \\
\hline \multirow{2}{*}{$\begin{array}{l}\text { ensi (Hz) } \\
\text { ) }\end{array}$} & 50.045 & 50.04 & 50.033 & 50.04 \\
\hline & 11.113 & 11.289 & 11.369 & 11.99 \\
\hline A) & 5.9375 & 5.8711 & 5.9669 & 5.6893 \\
\hline \multirow[t]{3}{*}{$\overline{\text { AR) }}$} & 12.6 & 12.725 & 12.84 & 13.271 \\
\hline & 0.882 & 0.8872 & 0.8855 & 0.9034 \\
\hline & 0.8855 & 0.8882 & 0.8861 & 0.9044 \\
\hline
\end{tabular}

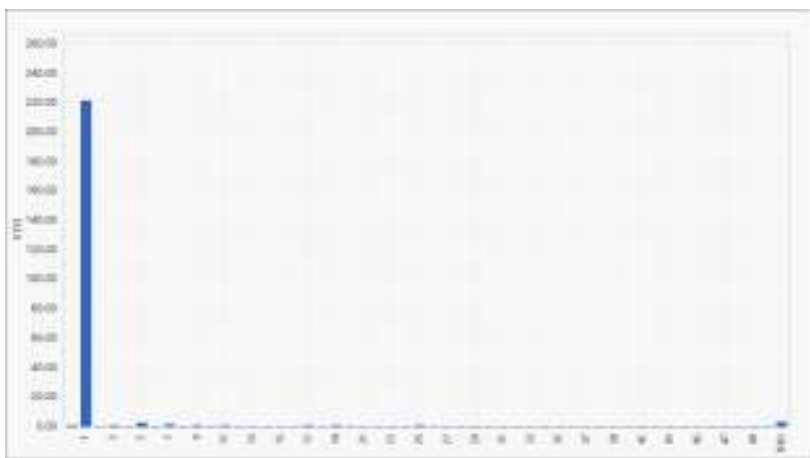

Gambar 4.9 Sprektrum harmonisa tegangan pada jam 10.15

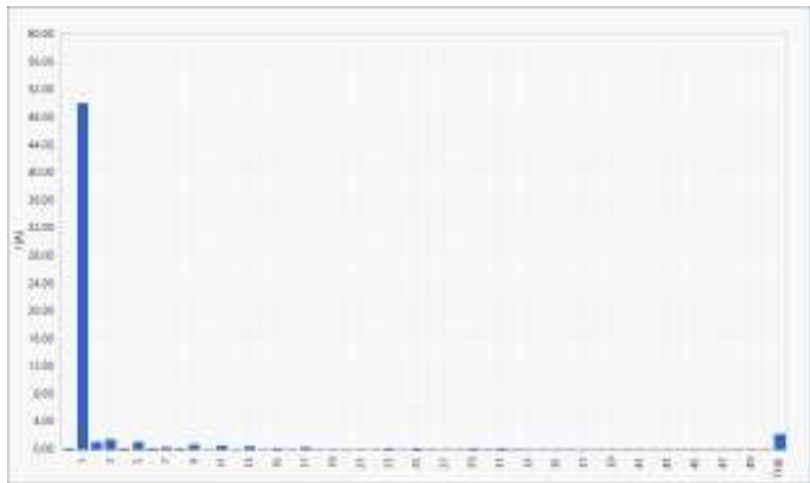

Gambar 4.10 Sprektrum harmonisa arus pada jam 10.15

Berdasarkan hasil pengukuran pada fasa R pada Gedung Rektorat Universitas Khairun daya aktif fasa $\mathrm{R}$ berkisar antara 9,1717 kW - 12,238 kW, daya reaktif berkisar dari 10,893 kVAR - 13,561 kVAR, dan daya semu 5,7688 VA 5,9889 VA. Total harmonisa distorsi tegangan dan arus berturut-turut berkisar antara $1.1636 \%-1,2527 \%$ dan 3,3446\% - 4,2300\%, sedang sprektrum harmonisa tegangan dan arus pada jam 10.15 berturut-turut 1,2429\% dan 4,4216\% ini menunjukan bahwa walaupun terjadi perubahan frekuensi tegangan dan arus dari nilai fundamentalnya tetapi masih 
memenuhi standar harmamonisa dari IEEE No. 519-1992 yaitu tidak melebih 5\% untuk harmonisa tegangan dan 15\% untuk harmonisa arus. Distorsi harmonisa akibat beban tak linier pada fasa R yang terendah terjadi jam 11.00 yaitu 0,882 sedangkan yang tertinggi sebesar 0,9034 pada jam 11.45.

b. Analisis Pada Fasa S

Analisis pada Fasa S ini menggunakan data rekapitulasi fasa S yang terlihat pada Tabel 4.10, sedang spectrum harmonisa tegangan dan arus dapat dilihat pada gambar 11 dan gambar 12

\begin{tabular}{|c|c|c|c|c|}
\hline \multirow{2}{*}{ Parameter } & \multicolumn{4}{|c|}{ Wakts Peanghemra } \\
\hline & fan 10.00 & Sam 10.15 & Inan 10.39 & $J a=10.45$ \\
\hline 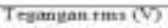 & 78.9 & 229.07 & 21898 & 21851 \\
\hline Arux rma (A) & 72.696 & 71.936 & 72662 & 72.404 \\
\hline Arun Netral (A) & 32965 & 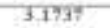 & 3.0854 & 3.4052 \\
\hline THD (\%) & 1721 & Tाजश & 17521 & 11866 \\
\hline THयक्षक & 10031 & Tाए5 & 9388 & 9.4927 \\
\hline Frobenten $(H x)$ & 90.041 & 500.44 & 50039 & 50033 \\
\hline$p(\mathrm{~kW})$ & 14340 & $1+181$ & 14200 & 14287 \\
\hline S(KVA) & क्रश्र & कामसक & 69793 & 65081 \\
\hline Q(E) & 15.952 & समल & 15912 & 15.831 \\
\hline DF & O. & $\sigma \operatorname{lng} 6$ & 0 wos & $0.15 \% 2$ \\
\hline DPy & 0.004 & 09035 & 0.9033 & 0.0056 \\
\hline \multirow{2}{*}{ Paraueter } & \multicolumn{4}{|c|}{ Walas Pengular = } \\
\hline & $3 \mathrm{sen} 11.00$ & Jam 11.15 & Jaun 11.30 & Jaen 11.45 \\
\hline Tegangau rus (V) & 21582 & 218.67 & 21501 & 215.61 \\
\hline Aros ras (A) & 72.727 & 72.807 & 74.804 & 73.438 \\
\hline Arus Netral (A) & 3.0657 & 1.0565 & $3.110 \pi$ & उ्र०डs \\
\hline THD $(\infty)$ & 11535 & 1. 100 & 1.5801 & $1.1 \times 37$ \\
\hline THDh $(\mathrm{MG})$ & 9.728 & 10.019 & 12.858 & 10.871 \\
\hline Frebuatii $(\mathrm{Hx})$ & 50.045 & 50.04 & 50.033 & 50.04 \\
\hline$p(k w)$ & 14279 & 14.272 & 14725 & 14359 \\
\hline 5 OVN & 7.0203 & 70547 & 70087 & 7.1800 \\
\hline Q(KVARO & 15913 & 15.921 & 16.3018 & 16.055 \\
\hline $\mathrm{PF}$ & 6.8973 & 08965 & 0.9029 & 0.8944 \\
\hline DPF & 0.9027 & 09014 & 0911 & 0.9002 \\
\hline
\end{tabular}

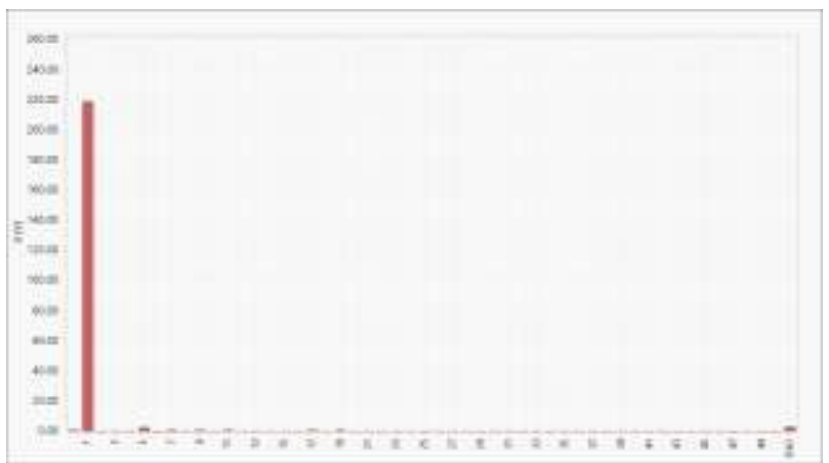

Gambar 4.11 Sprektrum harmonisa tegangan pada jam 10.15

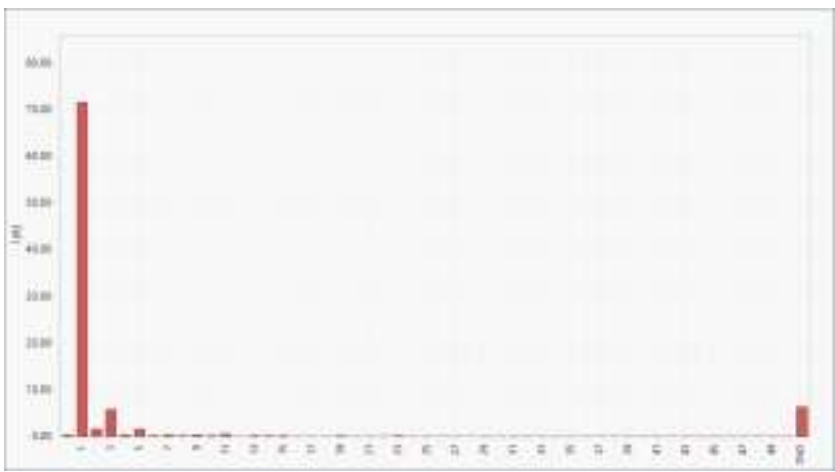

Gambar 4. 12 Sprektrum harmonisa arus pada jam 10.15

Berdasarkan hasil pengukuran pada fasa S pada Gedung Rektorat Universitas Khairun daya aktif fasa S berkisar antara $14,181 \mathrm{~kW}-14,725 \mathrm{~kW}$, daya reaktif berkisar dari $15,764 \mathrm{kVAR}-16.308 \mathrm{kVAR}$, dan daya semu $6.8847 \mathrm{VA}-$ 7.0547 VA. Total harmonisa distorsi tegangan dan arus berturut-turut berkisar antara 1.1485\% - 1.1966\% dan 
$8.8528 \%$ - $12.888 \%$, sedang sprektrum harmonisa tegangan dan arus pada jam 10.15 berturut-turut $1.1485 \%$ dan 8.8528\%. Hasil pengukuran fasa S nilai THD tegangan dan arus juga masih memenuhi standar IEEE No. $519-1992$.

Distorsi harmonisa akibat beban tak linier pada fasa S yang terendah terjadi jam 11.00 yaitu 0,8973 sedangkan yang tertinggi sebesar 0,9029 pada jam 11.30 .

c. Analisis Pada Fasa T

Analisis pada Fasa $\mathrm{T}$ ini menggunakan data rekapitulasi fasa $\mathrm{T}$ yang terlihat pada Tabel 4.12, sedang spectrum harmonisa tegangan dan arus dapat dilihat pada gambar 13 dan gambar 14

\begin{tabular}{|c|c|c|c|c|}
\hline \multirow{2}{*}{ Parameter } & \multicolumn{4}{|c|}{ Wakisu Peagukaran } \\
\hline & $\operatorname{san} 10.00$ & Jam 10.15 & $\operatorname{Sam} 10.30$ & $\operatorname{San} 10.45$ \\
\hline 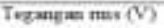 & 221.86 & $2210 \mathrm{Ot}$ & 22091 & 22096 \\
\hline Arus mav $(A)$ & 54.771 & 63.472 & 64.734 & 63.900 \\
\hline Avus Netral (A) & 32967 & 3.1737 & 3.0864 & $3+052$ \\
\hline $\mathrm{THO}_{2}(\mathrm{C})$ & 1.4399 & 1,3361 & 2.1322 & 13655 \\
\hline \multirow{3}{*}{$\begin{array}{l}\mathrm{THD}(\mathrm{CS}) \\
\text { Froinensi }(\mathrm{H} z) \\
\mathrm{P}(\mathrm{aW})\end{array}$} & 5.087 & 4.3918 & 37857 & 6.0864 \\
\hline & 50.041 & 30044 & 50.033 & 50033 \\
\hline & 1171 & 13.655 & 14.004 & 13515 \\
\hline$S(k V A)$ & 72472 & 3.0213 & 29012 & 29255 \\
\hline \multirow{2}{*}{$\begin{array}{l}\text { Q } \$ \text { QVAR } \\
\text { DF }\end{array}$} & D2TSi & 14028 & 14301 & 14121 \\
\hline & $0 \% 3 \%$ & 0.0756 & 09792 & 69489 \\
\hline DeF & 0.965 & 0.9765 & 0.98 & 09806 \\
\hline \multirow{2}{*}{ Param cter } & \multicolumn{4}{|c|}{ Wakcou Feagnkaran } \\
\hline & $\operatorname{Sat} 11.00$ & Jam 11.15 & $\operatorname{Jam} 1130$ & Jam 11.45 \\
\hline Teuangm ans (V) & 220.16 & 219.87 & 219.7 & 2795 \\
\hline Arus mis (A) & $6 \% 696$ & 68303 & 90.148 & 702286 \\
\hline Arui Netral (A) & $3.068 \%$ & 3.0805 & 3iाझ्र & 3048 \\
\hline THD: (N) & 1.3762 & 1.4649 & 13962 & 1.3828 \\
\hline \multirow{3}{*}{$\begin{array}{l}\text { THD, }(6) \\
\text { Frekemai }\left(\mathrm{H}_{2}\right) \\
\text { P(low) }\end{array}$} & 4.4633 & 5.2717 & 65574 & 0.0273 \\
\hline & 50.045 & 5004 & 50.033 & 50.04 \\
\hline & 11.113 & 14741 & 35.17 & 15.157 \\
\hline SCONA & 5.9575 & 2.8099 & 2781 & 2.8033 \\
\hline \multirow{2}{*}{$\begin{array}{l}\text { Q(KVAR) } \\
\text { p) }\end{array}$} & 12.6 & 15.019 & 15.411 & 15.14 \\
\hline & $0 . \$ 82$ & 0.9816 & 0.9843 & 09853 \\
\hline DDE & 08855 & 0.0539 & a.986 & 09659 \\
\hline
\end{tabular}

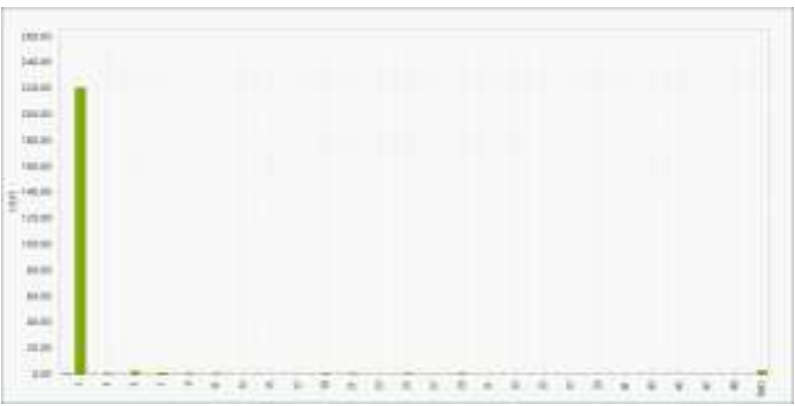

Gambar 4.13 Sprektrum harmonisa tegangan pada jam 10.15

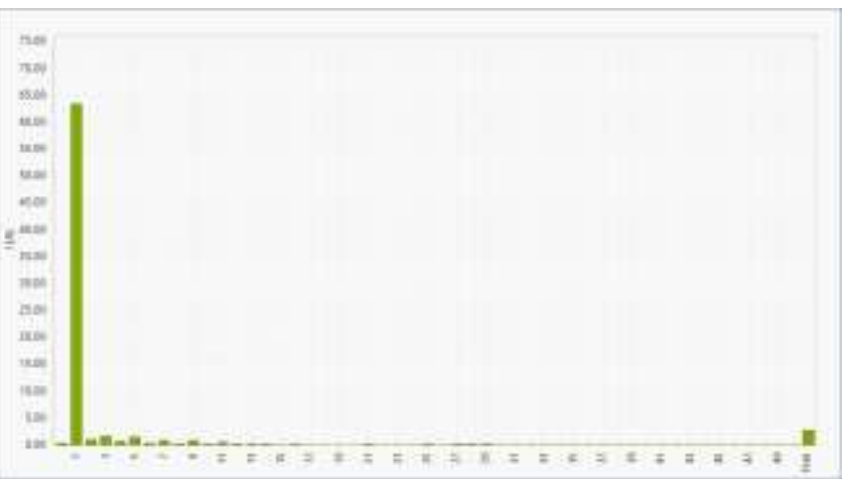

Gambar 4.14 Sprektrum harmonisa arus pada jam 10.15 
Berdasarkan hasil pengukuran pada fasa $\mathrm{T}$ pada Gedung Rektorat Universitas Khairun daya aktif fasa $\mathrm{T}$ berkisar antara $11.711 \mathrm{~kW}-15.17 \mathrm{~kW}$, daya reaktif berkisar dari $12.151 \mathrm{kVAR}-15.414 \mathrm{kVAR}$, dan daya semu $2.7184 \mathrm{kVA}-$ $3.2432 \mathrm{kVA}$. Total harmonisa distorsi tegangan dan arus berturut-turut berkisar antara $1.3322 \%-1.4649 \%$ dan $3.7887 \%-6.6273 \%$. Hasil pengukuran fasa T nilai THD tegangan dan arus juga masih memenuhi standar IEEE No. 519-1992.

Distorsi harmonisa akibat beban tak linier pada fasa $\mathrm{T}$ yang terendah terjadi jam 11.00 yaitu 0,882 sedangkan yang tertinggi sebesar 0,9843 pada jam 11.30 .

\subsection{KESIMPULAN}

Dari hasil pembahasan bahwa kualitas daya pada trafo distribusi di Universitas Khairun yang dilihat dari total harmonic distorsi tegangan (THDv), total harmonic distorsi arus (THDi), dan distorsi distorsi faktor daya dapat disimpulkan sebagai berikut :

1. Total harmonic distorsi tegangan (THDv) pada fasa R berkisar antara $1.1636 \%$ - 1,2527\%, fasa S berkisar antara $1.1485 \%$ - 1.1966\%, dan fasa T 1.3322\% - 1.4649\%, bila dibandingkan dengan standar IEEE No. 519-1992, maka THDV masih memenuhi.

2. Total harmonic distorsi arus (THDi) pada fasa R berkisar antara 3,3446\% - 4,2300\%, fasa S $8.8528 \%-12.888 \%$, dan fasa T 3.7887\% -6.6273\%, bila dibandingkan dengan standar IEEE No. 519-1992, maka THD I masih memenuhi.

3. Distorsi faktor daya pada masing-masing fasa masih terlihat normal yaitu pada fasa $\mathrm{R}$ yang terendah terjadi jam 11.00 yaitu 0,882 sedangkan yang tertinggi sebesar 0,9034 pada jam 11.45, fasa S terendah terjadi jam 11.00 yaitu 0,8973 sedangkan yang tertinggi sebesar 0,9029 pada jam 11.30, dan fasa $\mathrm{T}$ yang terendah terjadi jam 11.00 yaitu 0,882 sedangkan yang tertinggi sebesar 0,9843 pada jam 11.30 .

\section{REFERENCES}

[1] Dugan, Roger .. "Electrical Power System Quality”, New York, Marcell Deker. 1996

${ }_{2}$ ] Harsono, T dan Pratilastiarso, J.. "Harmonisa dan Pengaruhnya pada faktor Daya”. Jurnal IES 2003

[3] Julius Sentosa Setiadji, Tabrani Machmudsyah, Yohanes Cipta Wijaya, "Pengaruh Harmonisa Pada Gardu Trafo Tiang Daya 100 kVA di PLN APJ Surabaya Selatan”, Jurnal UK Petra Surabaya, 2006.

[4] P. N. Enjeti, et. all, "Analysis and design of a new active power filter to cancel neutral current harmonisas in thereephase fourwire electric distribution sistem”, IEEE Trans. Power delivery, 1996, pp. 736-744.

[5] Permadi, S.B.. "Studi Harmonisa Tegangan dan Arus di Gedung A Universitas Kristen Petra Surabaya". Skripsi Sarjanapada FTI UK Petra Surabaya:tidak diterbitkan. 2004

[6] Syafrudin, Pekik A. Dahono, Sukisno, T.M Soelaiman, "Analisis Penggunaan autotrafo penggeser fasa sebagai minimisator harmonisa arus di sistem distribusi tenaga listrik”, Proceedings Institut Teknologi Bandung, 1999.

[7] Winarko K.,."Studi Kualitas Daya Terhadap Komputer Di Gedung P Universitas Kristen Petra”. Skripsi Sarjana pada FTI UK Petra Surabaya: tidak diterbitkan. 2002 